\title{
Isolation and characterization of microsatellite loci from an endangered tree species, Toona ciliata var. pubescens
}

\author{
J. Liu ${ }^{1}$, Z.-X. Sun ${ }^{2}$, Y.-T. Chen ${ }^{1}$ and J.-M. Jiang ${ }^{1}$ \\ ${ }^{1}$ Research Institute of Subtropical Forestry, Chinese Academy of Forestry, \\ Hangzhou, Zhejiang, China \\ ${ }^{2}$ State Key Laboratory of Rice Biology, \\ China National Rice Research Institute, Hangzhou, Zhejiang, China \\ Corresponding author: J. Liu \\ E-mail: ywliu2005@163.com
}

Genet. Mol. Res. 11 (4): $4411-4417$ (2012)

Received March 9, 2012

Accepted June 22, 2012

Published September 19, 2012

DOI http://dx.doi.org/10.4238/2012.September.19.4

\begin{abstract}
Toona ciliata var. pubescens is considered an endangered tree species native to China. In order to help develop a conservation program for this species, we evaluated its genetic diversity and population genetics. We isolated microsatellite DNA loci using streptavidin beads. A genomic library, enriched with microsatellites, was constructed and screened by sequencing. We detected 8 polymorphic microsatellite loci from the tree tissue samples. The population of $T$. ciliata var. pubescens used in this study is located within the Guanshan National Nature Reserve, Jiangxi Province, China. Sixty-five individuals were collected for the study. The Guanshan population was split into two subpopulations due to terrain. The number of alleles per locus ranged from 2 to 6 , with expected heterozygosity from 0.2386 to 0.6772 . Four of the 8 loci, except loci Tc02, Tc04, Tc05, and Tc07 showed no significant departure from Hardy-Weinberg equilibrium. The mean observed heterozygosity was 0.59 . The average coefficient of genetic differentiation between the two subpopulations was quite low $\left(F_{\mathrm{ST}}=\right.$
\end{abstract}


0.0235). The level of gene flow $\left(N_{\mathrm{m}}\right)$ was 10.39 , reflecting a high degree of gene flow between the two subpopulations.

Key words: Microsatellite loci; Endangered tree; Isolation

\section{INTRODUCTION}

Toona ciliata var. pubescens is a deciduous, broad-leaved, fast growing tree species, which belongs to the family Meliaceae. Flowers of this species are small, and pollen spreads mainly by wind. The species is known as "Chinese mahogany", the color of the wood is red, and wood grain is very beautiful. Therefore, T. ciliata var. pubescens is a valuable timber species both economically and developmentally (Zhang et al., 2006). The number of individuals of this species is decreasing due to environmental changes, logging, and their slow regeneration. This tree species is classified as being under second-class protection of endangered species in China Plant Red Data Book. It is also listed as a rare and endangered species in the distribution of provinces (Lou and Jin, 2000; Zhang, 2000; Liu and Wu, 2005). Therefore, genetic diversity conservation studies of this species are critical. Preliminary reports regarding this species included ecological characteristics (Zhang et al., 2006), genetic improvement (Liu et al., 2008), community structure (Liu et al., 2010), and so on. In order to effectively protect this tree species, information regarding the level of genetic variation and the extent of genetic differentiation within and among natural populations is necessary.

Highly informative genetic markers are essential for assessing genetic improvement processes, such as clonal identification, certification of controlled crosses, identification of species and hybrids, genome mapping, and marker-assisted early selection. Such markers are valuable in analyzing genetic diversity and structure and in developing effective strategies for conservation and sustainable management of forest genetic resources. Some molecular markers, including random amplified polymorphic DNA (Bellini et al., 2003), amplified fragment length polymorphism (Cardoso et al., 2000), and inter-simple sequence repeat (Culley and Wolfe, 2001), have been used for studying population genetics. In recent years, microsatellites or simple sequence repeats (SSR) have become popular tools for population and conservation genetics (Chase et al., 1996a), due to codominance and high polymorphism rates of SSR (Tautz and Renz, 1984; Morgante and Olivieri, 1993; White and Powell, 1997; Arif et al., 2010; Vik et al., 2010). Although initially developed from studies based on human and mammalian biology (Love et al., 1990), their high information content and relative ease of use via the polymerase chain reaction (PCR) results in SSRs being an ideal tool for many ecological genetic applications. These DNA markers also have been developed for a small number of forest tree species (Echt et al., 1996; Chase et al., 1996b; Pfeiffer et al., 1997; Latouche Halle et al., 2002; Draheim et al., 2009). However, the application of microsatellites in plant species has been limited due to the associated difficulties such as technical details, cost, and the relatively time-consuming nature of obtaining these markers. Recently, different isolation protocols have been developed, and the cost and time involved in their isolation have been reduced (Zane et al., 2002). Thus, it is now possible for us to isolate microsatellite DNA.

Herein, we report the isolation and characterization of 8 microsatellite loci from the genomic DNA of T. ciliata var. pubescens using an improved method with streptavidin beads. The results of this study will facilitate the analysis of the genetic structure and gene flow of natural populations, which will aid in developing strategies for conserving the endangered tree species. 


\section{MATERIAL AND METHODS}

\section{Plant material and collection}

The population of T. ciliata var. pubescens used in this study is located within the native range of Toona in China, in an area of 28 ha located in the Guanshan National Nature Reserve, Jiangxi Province, China, distributed in the geographic range from $28^{\circ} 30^{\prime}$ to $28^{\circ} 40^{\prime}$ in latitude, and from $114^{\circ} 29^{\prime}$ to $114^{\circ} 45^{\prime}$ in longitude. The Guanshan population was split into 2 subpopulations (Donghe, $\mathrm{N}=37$; Xihe, $\mathrm{N}=28$ ) due to terrain. Leaf material for DNA analysis was collected in 2008. Individual trees were sampled from these sites using silica gel to dry the leaf material.

\section{Preparation of genomic DNA}

Genomic DNA was extracted from dried leaves by modified cetyltrimethylammonium bromide (CTAB) method (Dong et al., 2010). After purification, the genomic DNA was partially digested with BamHI and HindIII (TaKaRa, Dalian, China). The restriction endonuclease was inactivated in $70^{\circ} \mathrm{C}$ water for $15 \mathrm{~min}$. The products were ligated with 2 adapters (Adapter 1: oligo A, 5'-ATCTCCATGATTACGCCAG-3' annealed to oligo B, 5'-GATCCTGGCGTAAT CATGGAGAT-3'; Adapter 2: oligo C, 5'-TACTGGTACTAATGCGGTA-3' annealed to oligo D, 5'-AGCTTACCGCATTAGTACCAGTA-3').

\section{Microsatellite enrichment using streptavidin beads}

PCR was performed in a $15-\mu \mathrm{L}$ reaction volume with the ABI GeneAmp 9600 PCR System (ABI, USA). The reaction mixture contained $2 \mu \mathrm{L}$ ligation products, $1 \mathrm{X}$ PCR buffer, $0.3 \mathrm{mM}$ dNTP, $0.5 \mu \mathrm{M}$ oligo A, $0.5 \mu \mathrm{M}$ oligo D, and $0.5 \mathrm{U}$ rTaq DNA polymerase (TaKaRa). The PCR conditions were $94^{\circ} \mathrm{C}$ for $4 \mathrm{~min}$ followed by 20 cycles of $94^{\circ} \mathrm{C}$ for $30 \mathrm{~s}, 55^{\circ} \mathrm{C}$ for $30 \mathrm{~s}, 72^{\circ} \mathrm{C}$ for $1 \mathrm{~min}$, and final elongation for $10 \mathrm{~min}$ at $72^{\circ} \mathrm{C}$. Ten microliters of $500 \mathrm{pM}$ biotin-labeled (AG) $)_{10}$ probe and $3 \mu \mathrm{L}$ elution buffer $20 \mathrm{X} \mathrm{SSC}\left(3.0 \mathrm{M} \mathrm{NaCl}, 0.3 \mathrm{M} \mathrm{C}_{6} \mathrm{H}_{5} \mathrm{O}_{7} \mathrm{Na}_{3} .2 \mathrm{H}_{2} \mathrm{O}\right)$ were added to $100 \mu \mathrm{L}$ PCR products. The mixture was denatured at $95^{\circ} \mathrm{C}$ for $10 \mathrm{~min}$ and then hybridized at $65^{\circ} \mathrm{C}$ for $1 \mathrm{~h}$.

One tube of streptavidin beads ( $600 \mu \mathrm{L}$; Promega, USA) was washed according to manufacturer instructions. The hybridization reaction products were added to the tube with beads and agitated by gentle shaking for $45 \mathrm{~min}$ at room temperature. The reaction products were washed with $0.08 \mathrm{X}$ SSC 3 times. Microsatellite-enriched DNA was eluted from streptavidin beads with $100 \mu \mathrm{L} \mathrm{ddH_{2 }} \mathrm{O}$ (preheated to $95^{\circ} \mathrm{C}$ ), and then made double-stranded by PCR. The PCR conditions were the same as the protocol described above. The reaction mixture contained $1 \mu \mathrm{L}$ microsatellite-enriched DNA, and the reaction cycles numbered 35 .

\section{Construction of enriched libraries and characterization of enriched microsatellites}

The PCR products were cloned into a pMD 18-T vector (TaKaRa) using T4 DNA ligase at $16^{\circ} \mathrm{C}$ for $16 \mathrm{~h}$. Ligated DNA was transfected into Escherichia coli DH5 $\alpha$ following manufacturer recommendations and plated on $150-\mathrm{mm}$ culture plates with lysogeny broth agar, X-gal, and isopropyl $\beta$-D-1-thiogalactopyranoside (IPTG). The positive clones were sent to a company for sequencing. Primers were designed using Primer 5.0 and were synthesized by Sangon (Shanghai, China). 


\section{Analysis of microsatellite polymorphisms}

Microsatellite polymorphisms were analyzed by PCR using T. ciliata var. pubescens samples. PCR was performed in a $15-\mu \mathrm{L}$ volume containing $1 \mathrm{X}$ PCR buffer, $0.3 \mathrm{mMdNTP}$, $0.3 \mu \mathrm{M}$ of each primer, $0.5 \mathrm{U}$ rTaq DNA polymerase (TaKaRa), and $30 \mathrm{ng}$ genomic DNA. The annealing temperature was from $52^{\circ}$ to $55^{\circ} \mathrm{C}$. The PCR conditions were $94^{\circ} \mathrm{C}$ for $4 \mathrm{~min}, 35$ cycles $\left(94^{\circ} \mathrm{C}\right.$ for $30 \mathrm{~s}, 52$ to $55^{\circ} \mathrm{C}$ for $30 \mathrm{~s}, 72^{\circ} \mathrm{C}$ for $\left.1 \mathrm{~min}\right)$, and $72^{\circ} \mathrm{C}$ for $10 \mathrm{~min}$. The PCR products were analyzed on an $8 \%(\mathrm{w} / \mathrm{v})$ polyacrylamide gel. Electrophoresis was performed at $100-\mathrm{W}$ constant power for 2 to $2.5 \mathrm{~h}$. PCR amplifications were visualized by silver staining according to the manufacturer protocol (Promega, 1995). A 10-bp DNA ladder (Invitrogen, USA) was used as a size standard. The mean number of alleles per locus $\left(N_{\mathrm{A}}\right)$, effective number of alleles $\left(N_{\mathrm{E}}\right)$, mean observed heterozygosity $\left(H_{\mathrm{O}}\right)$, expected heterozygosity $\left(H_{\mathrm{E}}\right)$, gene flow $\left(N_{\mathrm{m}}\right)$, and Hardy-Weinberg equilibrium were computed using Microsoft Window-based Freeware for Population Genetic Analysis (POPGENE) version 3.2.

\section{RESULTS}

\section{Identification and characterization of microsatellite loci}

The (AG) $)_{\mathrm{n}}$-enriched genomic library of T. ciliata var. pubescens was screened with an $(\mathrm{AG})_{10}$ oligonucleotide repeat. Approximately 100 clones were evaluated in the primary screen, from which 35 were scored as positive. Twenty of these clones were sequenced, and 8 of the sequenced fragments contained at least 5 repeats. Primers were designed using Primer 5.0 and synthesized by Sangon. In addition to the expected (AG/CT) repeats, other repeat sequence motifs were discovered in the sequenced clones, including (TTTCTC $)_{7}$. In many positive clones, 8 primers were developed (Table 1). The 8 microsatellite loci were subsequently used to assess levels of variation in a natural population of $T$. ciliata var. pubescens and the genetic structure of the same population when split into 2 subpopulations.

\begin{tabular}{|c|c|c|c|c|c|}
\hline Loci & $\begin{array}{l}\text { GenBank } \\
\text { accession No. }\end{array}$ & Primer sequence $\left(5^{\prime}-3^{\prime}\right)$ & Repeat motif & $\operatorname{Tm}\left({ }^{\circ} \mathrm{C}\right)$ & Allele size (bp) \\
\hline Tc01 & DQ453903 & $\begin{array}{l}\text { F: GACTCGTGACACTTAGCCTGTA } \\
\text { R: CTGGCGTAATCATGGTCATAC }\end{array}$ & $(\text { TTTCTC })_{7}$ & 55 & $121-231$ \\
\hline $\mathrm{Tc} 02$ & DQ453904 & $\begin{array}{l}\text { F: TAGGAAAGGCAAGGTGGG } \\
\text { R: GGGTGGTCGATGAGGGTT }\end{array}$ & $(\mathrm{AG})_{14}$ & 55 & $109-120$ \\
\hline $\mathrm{Tc} 03$ & DQ453905 & $\begin{array}{l}\text { F: AGTAATAGCCTGTAGAGCAG } \\
\text { R: AGAGTGGGGTGGTCGATGAG }\end{array}$ & $(\mathrm{AG})_{13}$ & 55 & $120-242$ \\
\hline Tc04 & DQ453906 & $\begin{array}{l}\text { F: GAAACCAGCAGGCAGAGC } \\
\text { R: GAAGAAGGGTGAGCGAGA }\end{array}$ & $(\mathrm{AG})_{10}$ & 55 & $110-230$ \\
\hline Tc05 & DQ453907 & $\begin{array}{l}\text { F: GATTACGCCAGGCAAACG } \\
\text { R: TTGAATATGGGAGAAGGT }\end{array}$ & $(\mathrm{CT})_{6}$ & 55 & $230-290$ \\
\hline Tc06 & DQ453912 & $\begin{array}{l}\text { F: ATGGATGAGTGTGCGATAGG } \\
\text { R: TGTGATGTAGGAGTCTGAAC }\end{array}$ & $(\mathrm{TC})_{7}$ & 55 & $182-280$ \\
\hline Tc07 & DQ453914 & $\begin{array}{l}\text { F: TGTCTCAGTTTATGCTGGCGT } \\
\text { R: CTGCCCAATCAACAAGAG }\end{array}$ & $(\mathrm{TC})_{8}$ & 55 & $170-260$ \\
\hline Tc08 & DQ778303 & $\begin{array}{l}\text { F: TCAATGCAATTTAGGAGGAA } \\
\text { R: TGCTTGTTGAACCCTGTG }\end{array}$ & $(\mathrm{GA})_{8}$ & 52 & 240-291 \\
\hline
\end{tabular}

$\mathrm{Tm}=$ melting temperature. 


\section{Level of polymorphism of microsatellite loci}

In the 8 microsatellite loci that were surveyed, we identified a total of 27 alleles among 65 individuals in the Guanshan population. The $N_{\mathrm{A}}, N_{\mathrm{E}}, H_{\mathrm{O}}, H_{\mathrm{E}}$, and deviations from Hardy-Weinberg equilibrium are shown in Table 2. In the Guanshan population, 3.38 alleles were detected over all loci. When splitting this population into 2 subpopulations, 24 alleles were found in the Donghe and Xihe subpopulations. The average $H_{\mathrm{O}}$ was 0.59 in the Guanshan population; the Donghe subpopulation had a mean $H_{\mathrm{O}}$ of 0.66 and the Xihe subpopulation had a mean $H_{\mathrm{O}}$ of 0.50 .

\begin{tabular}{|c|c|c|c|c|c|}
\hline Population & Locus & $N_{\mathrm{A}}$ & $N_{\mathrm{E}}$ & $H_{\mathrm{E}}$ & $H_{\mathrm{O}}$ \\
\hline \multirow[t]{8}{*}{ Guanshan } & $\mathrm{Tc} 01$ & 2 & 1.3133 & 0.2386 & 0.1380 \\
\hline & $\mathrm{Tc} 02$ & 2 & 1.811 & 0.4478 & $0.6769 * *$ \\
\hline & $\mathrm{Tc} 03$ & 4 & 2.022 & 0.5459 & 0.6308 \\
\hline & Тc04 & 3 & 2.2138 & 0.5483 & $0.9385 * *$ \\
\hline & Тc05 & 2 & 1.9493 & 0.487 & $0.8387 * *$ \\
\hline & Тc06 & 6 & 3.0981 & 0.6772 & 0.7000 \\
\hline & $\mathrm{Tc} 07$ & 3 & 2.4229 & 0.5873 & $0.5000 * *$ \\
\hline & $\mathrm{Tc} 08$ & 5 & 1.5921 & 0.3719 & 0.3636 \\
\hline Mean (St. Dev) & & $3.38(1.51)$ & $2.08(0.55)$ & $0.49(0.14)$ & $0.59(0.29)$ \\
\hline \multirow[t]{8}{*}{ Donghe } & $\mathrm{Tc} 01$ & 2 & 1.2389 & 0.1928 & 0.1252 \\
\hline & $\mathrm{Tc} 02$ & 2 & 1.8096 & 0.4474 & $0.6757 * *$ \\
\hline & $\mathrm{Tc} 03$ & 4 & 2.1992 & 0.5453 & 0.6757 \\
\hline & $\mathrm{Tc} 04$ & 2 & 1.9869 & 0.4967 & $0.9189 * *$ \\
\hline & $\mathrm{Tc} 05$ & 2 & 1.9983 & 0.4996 & $0.9706 * *$ \\
\hline & Tc06 & 6 & 2.5806 & 0.6125 & 0.8788 \\
\hline & $\mathrm{Tc} 07$ & 3 & 2.7923 & 0.6419 & 0.7647 \\
\hline & $\mathrm{Tc} 08$ & 3 & 1.3662 & 0.2681 & 0.3125 \\
\hline Mean (St. Dev) & & $3.0(1.41)$ & $1.99(0.54)$ & $0.46(0.16)$ & $0.66(0.33)$ \\
\hline \multirow[t]{8}{*}{ Xihe } & $\mathrm{Tc} 01$ & 2 & 1.4152 & 0.2934 & 0.1322 \\
\hline & $\mathrm{Tc} 02$ & 2 & 1.8127 & 0.4483 & $0.6786 * *$ \\
\hline & $\mathrm{Tc} 03$ & 4 & 2.0604 & 0.5147 & 0.5714 \\
\hline & $\mathrm{Tc} 04$ & 3 & 2.4771 & 0.5963 & $0.9643 * *$ \\
\hline & $\mathrm{Tc} 05$ & 2 & 1.8127 & 0.4483 & $0.6786 * *$ \\
\hline & $\mathrm{Tc} 06$ & 4 & 3.3986 & 0.7058 & 0.4815 \\
\hline & $\mathrm{Tc} 07$ & 3 & 1.8914 & 0.4713 & $0.1786^{* *}$ \\
\hline & $\mathrm{Tc} 08$ & 4 & 1.9702 & 0.4924 & 0.4348 \\
\hline Mean (St. Dev) & & $3.0(0.93)$ & $2.10(0.60)$ & $0.49(0.12)$ & $0.50(0.30)$ \\
\hline
\end{tabular}

Values with asterisks showed significant departure from Hardy-Weinberg equilibrium with $\chi^{2}$ tests $(\mathrm{P}<0.01)$.

The average $H_{\mathrm{E}}$ was 0.49 , ranging from 0.2386 to 0.6772 . There were no significant departures from Hardy-Weinberg expectations for the mean $H_{\mathrm{O}}$ in all populations. Significant departure from Hardy-Weinberg equilibrium was found by using $\chi^{2}$ goodness-of-fit tests for some individual loci. The departures from Hardy-Weinberg equilibrium were due to an excess of heterozygosity $\left(F_{\text {IS }}=-0.1988\right)$.

\section{Differentiation among subpopulations}

The average coefficient of genetic differentiation $\left(F_{\mathrm{ST}}\right)$ was 0.0235 , ranging from 0 to 0.0391 , which indicated that $97.65 \%$ of the genetic variation was within subpopulations, 
while $2.35 \%$ of the genetic variation was between subpopulations. The genetic differentiation among populations $\left(F_{\mathrm{ST}}\right)$ is inversely related to $N_{\mathrm{m}}$ (number of migrants per generation). If the mean value for $F_{\mathrm{ST}}$ is substituted into the equation: $N_{\mathrm{m}}=\left(1-F_{\mathrm{ST}}\right) / 4 F_{\mathrm{ST}}$, a migration rate of 10.39 migrants per generation $\left(N_{\mathrm{m}}\right)$ is obtained.

\section{DISCUSSION}

An improved method using streptavidin-coated magnetic beads for the library enriched for microsatellite repeats was described in this study. The enrichment procedure used in this study helped us to capture (AG) ${ }_{\mathrm{n}}$ repeats from fragmented genomic DNA and to construct enriched libraries for the subtropical forest tree T. ciliata var. pubescens. Thirty-five percent of the clones tested positive. The rate of positive clones obtained by means of traditional methods usually ranged from as high as $12 \%$ to less than $0.4 \%$ (Zang et al., 2002). Therefore, the method for microsatellite isolation using selective hybridization based on biotin capture with streptavidin-coated magnetic beads is very efficient. Eight pairs of primers were designed from the sequence data using the Primer 5.0 software. Allelic polymorphism was found in the Guanshan population of T. ciliata var. pubescens.

In the current study, 8 polymorphic microsatellite loci were isolated and characterized in the Guanshan population and its 2 subpopulations for the first time. As shown in Table 2, the $N_{\mathrm{A}}$ per locus ranged from 2 to 6 , with an average of 3.38 across all loci in the Guanshan population as a whole. The $H_{\mathrm{O}}$ ranged from 0 to 0.9706 , averaging at 0.58 over all loci. The extent of genetic variation detected in the natural population of T. ciliata var. pubescens at Guanshan was higher than that of Swietenia humilis (White and Powell, 1997) and Carapa guianensis (Hall et al., 1994), which also belong to Meliaceae. Tc02, Tc04, and Tc05 significantly deviated from Hardy-Weinberg equilibrium due to heterozygosity excess.

The Guanshan population was divided into 2 subpopulations due to the habitat terrain. The coefficient of mean genetic differentiation between the 2 subpopulations was small $\left(F_{\mathrm{ST}}=\right.$ $0.0235)$. The average exchange of 1 individual per generation $\left(N_{\mathrm{m}}=1\right)$ was sufficient to prevent genetic drift. The gene flow between the 2 subpopulations was 10.39 based on Wright's $F_{\text {ST }}$. This indicated that genes exchanged frequently between individual trees.

\section{ACKNOWLEDGMENTS}

Research supported by the National Natural Science Foundation Project (Grant \#31100487) and the National Forestry Public Welfare Industry Research Project (Grant \#201104001). We sincerely thank Hu Guocheng, Liu Wenzhen, Luan Weijiang, and Zhuo Renying for their help. We also thank He Guiping, Wu Tianlin, and Li Jiangchuan for the collection of samples.

\section{REFERENCES}

Arif IA, Khan HA, Shobrak M, Al Homaidan AA, et al. (2010). Interpretation of electrophoretograms of seven microsatellite loci to determine the genetic diversity of the Arabian Oryx. Genet. Mol. Res. 9: 259-265.

Bellini E, Benelli C, Giordani E, Perria R, et al. (2003). Genetic and morphological relationships between possible Italian and Ancestral cultivars of persimmon. Acta Hortic. 601: 192-197.

Cardoso SR, Eloy NB, Provan J, Cardoso MA, et al. (2000). Genetic differentiation of Euterpe edulis Mart. populations 
estimated by AFLP analysis. Mol. Ecol. 9: 1753-1760.

Chase M, Kesseli R and Bawa K (1996a). Microsatellite markers for population and conservation genetics of tropical trees. Am. J. Bot. 83: 51-57.

Chase M, Moller C, Kesseli R and Bawa K (1996b). Long distance gene flow patterns precisely characterized by simple sequence repeats in a fragmented tropical tree population. Nature 383: 398-399.

Culley TM and Wolfe AD (2001). Population genetic structure of the cleistogamous plant species Viola pubescens Aiton (Violaceae), as indicated by allozyme and ISSR molecular markers. Heredity 86: 545-556.

Dong W, Huang SX, Chen R and Gui RY (2010). Comparison on DNA extraction methods from Betula alnoides leaves dried with silica gel. For. Res. 30: 36- 43.

Draheim H, Melissa C and Christopher WD (2009). Characterization of 14 microsatellite DNA markers for the tropical forest tree Virola surinamensis (Rol.) Warb. (Myristicaceae). Mol. Ecol. Notes 9: 1386-1388.

Echt CS, May-Marquardt P, Hseih M and Zahorchak R (1996). Characterization of microsatellite markers in eastern white pine. Genome 39: 1102-1108.

Hall P, Orrel LC and Bawa KS (1994). Genetic diversity and mating system in a tropical tree, Carapa guianensis (Meliaceae). Am. J. Bot. 81: 1104-1111.

Latouche Halle C, Ramboer A, Bandou E, Caron H, et al. (2002). Isolation and characterization of microsatellite markers in the tropical tree species Dicorynia guianensis (Caesalpinaceae). Mol. Ecol. Notes 2: 228-230.

Liu J, Chen YT, He GP, Yu GM, et al. (2008). A study on genetic variations of seedling traits of plus trees of Toona ciliata var. pubescens. Acta Agric. Univ. Jiangxiensis 30: 64-67.

Liu J, Chen YT, Luo YF, Jiang JM, et al. (2010). Study on community characters of Toona ciliata var. pubescens natural forest. For. Res. 23: 93-97.

Liu XZ and Wu HP (2005). Scientific Investigation and Research of Guanshan Nature Reserve in Jiangxi Province. China Forestry Publishing House, 118-120.

Lou LH and Jin SH (2000). Spermatophyta flora of Gutianshan nature reserve in Zhejiang. J. Beijing For. Univ. 22: 33-39.

Love JM, Knight AM, McAleer MA and Todd JA (1990). Towards construction of a high resolution map of the mouse genome using PCR-analysed microsatellites. Nucleic Acids Res. 18: 4123-4130.

Morgante M and Olivieri AM (1993). PCR-amplified microsatellites as markers in plant genetics. Plant J. 3: 175-182.

Pfeiffer A, Olivieri AM and Morgante M (1997). Identification and characterization of microsatellites in Norway spruce (Picea abies K.). Genome 40: 411-419.

Promega (1995). Technical Manual: Silver Sequence DNA Sequencing System. Promega Corporation, Madison.

Tautz D and Renz M (1984). Simple sequences are ubiquitous repetitive components of eukaryotic genomes. Nucleic Acids Res. 12: 4127-4138.

Vik U, Jorgensen MH, Kauserud H, Nordal I, et al. (2010). Microsatellite markers show decreasing diversity but unchanged level of clonality in Dryas octopetala (Rosaceae) with increasing latitude. Am. J. Bot. 97: 988-997.

White G and Powell W (1997). Isolation and characterization of microsatellite loci in Swietenia humilis (Meliaceae): an endangered tropical hardwood species. Mol. Ecol. 6: 851-860.

Zane L, Bargelloni L and Patarnello T (2002). Strategies for microsatellite isolation: a review. Mol. Ecol. 11: 1-16.

Zang L, Zang L and Patarnello T (2002). Microsatellite in different eukaryotic genomes: survey and analysis. Genome Res. 10: 967-981.

Zhang GF (2000). Study on rare and threatened plants of Anhui and their conservation. J. Anhui Normal Univ. 23: 36-39.

Zhang L, Guo LH and Du TZ (2006). The effects of ehading and soil water content on photosynthesis of Toona ciliata var. pubescens seedlings. J. Nanjing For. Univ. 30: 63-66. 